\title{
ІСТОРИЧНИЙ ШЛЯХ ВИНИКНЕННЯ ТА ПОШИРЕННЯ ДОМАШНЬОГО НАСИЛЬСТВА
}

\begin{abstract}
НЕРОД Микола Анатолійович - викладач циклу загальних та кримінальноправових дисциплін Київського центру первинної професійної підготовки «Академія поліції» навчально-наукового інституту № 1 Національної академії внутрішніх справ
\end{abstract}

DOI:10.32782/NP.2020.2.20

В статье исследованъл исторические
аспектьл возникновения и развития домашне-
го насилия. Проанализированъ особенности
домашнего насилия на разнъх втапах разви-
тия нашего государства.
Ключевъе слова: насилие, насилие в семъе,
домашнее насилие, жертва насилия.

Постановка проблеми

Останнім часом питання гендерної рівноваги та боротьби з гендерною дискримінацією набуло широкої популярності у всіх розвинених країнах, тим самим певною мірою відображаючи рівень розвитку суспільства, який досяг певного стану. На сьогодні існує нагальна потреба у вивченні генезису домашнього насильства шляхом вивчення наукових, історичних та релігійних джерел, законодавства в сучасній Україні, аналіз чинного законодавства, порівняння національної та західної історії домашнього насильства для подальшого визначення факторів та шляхів подолання його.

На жаль, насильство супроводжувало людей протягом усього шляху розвитку, маючи свій вияв у різних формах і видах. Особливий вплив насильство мало на такий класичний соціальний інститут, як сім'я. Вивчаючи формування і трансформацію суспільної свідомості до домашнього насильства та закріплення його в нормативних актах в історії вітчизняного держави, звернемо увагу на ряд обставин.
Аналіз останніх наукових досліджень і публікацій

Проблеми, що мали зв'язок $з$ дослідженнями щодо домашнього насильства, знайшли свій вияв у роботах видатних українських та закордонних вчених і правознавців. Порушенням прав людини у вигляді вчинення насильницьких дій, у тому числі щодо осіб жіночої статті, присвятили свої праці такі науковці, як В. С. Малишев, Ю. М. Антонян, Я. І. Гілинський, Т. А. Сидоренкова, В. М. Кудрявцев, К. А. Гурковська. Важливими в дослідженні історіографії проблеми домашнього насильства стали напрацювання вітчизняних та зарубіжних учених-гендеристів С. Айвазової, Н. Болотіної, М. Буроменського, О. Вороніної, В. Глиняного, О. Дашковської, А. Завадської, А. Кормич, Н. Аавриненко, I. Аавринчук, Н. Аніщук, К. Аевченко, А. Аеонтьєвої, О. Матвієнко, Т. Мельник.

\section{Виділення не вирішених раніше частин загальної проблеми}

Незважаючи на значну кількість наукових робіт у сфері насильства, зокрема домашнього насильства, історичний шлях виникнення та поширення його в Україні досліджений досить мало. У той же час питання історичного шляху розвитку домашнього насильства в Україні потребує подальшого дослідження.

Мета статті полягає в окресленні сутності, важливості вивчення історичних аспек- 
тів виникнення домашнього насильства як складного та історичного стійкого явища.

\section{Виклад основного матеріалу дослідження}

Утворена та зміцнена століттями система патріархальних відносин привела до формування безмежної влади батька і чоловіка у своїй родині. Патріархальність виявлялася в стосунках батьків і дітей і в стосунках між подружжям. До прийняття християнства у деяких слов'янських племен допускалася багатоженство, у зв'язку з цим особливого значення надавалося визнанню батьком своєї дитини.

3 прийняттям християнства змінюється і усвідомлення сімейного життя. Тепер шлюб дозволяється тільки з однією жінкою, а одним з гріхів стає перелюб. Прийняття християнства сприяло і зміні свідомості людей, переосмислення минулого встановленого порядку, цінностей, традицій. Після прийняття християнства відбувається рецепція візантійського шлюбно-сімейного законодавства, в основу якого було покладено канонічне уявлення про сімейне право.

На зорі вітчизняної державності і протягом тривалого періоду часу юридичного визначення сімейно-побутового насильства не існувало. У правовому регулюванні сімейних взаємин пріоритет віддавався питанням майнового характеру між членами сім’і, а особисті взаємини не знаходили достатнього відображення і грунтувалися в основному на церковному праві.

Знайомство із джерельною історичною базою дослідження дає змогу виокремити достатньо широке коло історичних пам'яток вітчизняного права, котрі регулювали відносини в цій сфері, а саме: Статути Володимира та Ярослава про церковні суди, Руська Правда, Статути Великого князівства Литовського 1529, 1566 та 1588 рр., «Права, за якими судиться малоросійський народ» 1743 р., «Уложення про покарання кримінальні та виправні» 1845 р. та 1885 р., Кримінальне Уложення 1903 р., Кримінальні кодекси радянської України 1922, 1927 та 1961 рр. й ін.

Звертаючись до основного джерела права Київської Русі - «Руська правда», відзначимо, що він не містить категоричних обме- жень щодо застосування насильства главою сім’і, тобто і законодавчо превалює практично необмежена влада батька і чоловіка. Княже законодавство цього ж періоду робило спробу захистити деякі права дітей, мова йде про Статут князя Ярополка, де, зокрема, ст. 24 свідчила наступне: "А ж дівка не восхоче заміж, а батько і мати силою дадуть, а що створити над собою - батько і мати єпископу у вині. Так само і юнак». Дана норма вводить заборону на насильницьку видачу заміж або одруження своїх дітей. Аналогічну думку містить і ст. 33 цього ж статуту, де забороняється перешкоджати бажанням дітей на шлюб.

Значну роль у формуванні стереотипу про домінуюче становище чоловіка над жінкою в сімейному житті відіграє релігія. Святі писання майже всіх основних релігій світу мають низку місць, у яких чітко стверджується, що чоловіки повинні мати перевагу над жінками у суспільстві. Ці місця впродовж історії використовувалися для виправдання і посилення підлеглого статусу жінок. Багато релігій терпимо ставляться до домінування чоловіків над жінками, а деякі 3 них дещо заохочують фізичне покарання жінок та дітей. Релігійні інституції історично сприяли існуванню суспільних і правових структур, установок і цінностей, які стверджують владу чоловіка.

Більшість релігійних норм щодо відносин між батьками та дітьми міститься у Старому Завіті у Притчах Соломонових, зокрема: «13:24 Хто шкодує різки своєї, той ненавидить сина; а хто любить, той 3 дитинства карає його»; «19:18 Карай сина свого, доки є надія, і не обурюйся його криком»; «22:15 Глупство прив’язалося до серця юнака; але виправна різка відкине гнів його від нього»; «23:13-14 Не залишай юнака без покарання; якщо покараєш його різкою, він не помре. Ти покараєш його різкою, і врятуєш душу від «29:15 Різка і викриття дають мудрість; але підліток, залишений без уваги, вчиняє сором матері» [1].

Слід зазначити, що наразі деякі представники церкви посилаються на те, що норми Старого Завіту є історією, а сучасні правила поведінки закріплено у Новому Завіті, в якому, проте, відносинам батьків та дітей 


\section{Кримінальне право, кримінальний процес та криміналістика}

не приділено такої уваги, як у Старому; деякі зазначають, що застосувати фізичні покарання до дітей можна лише у разі вчинення ними гріховних діянь, а не прогрішень. 3 огляду на те, що значна кількість українців є віруючими, релігійні норми доволі часто для них мають пріоритет над нормами права, які, у свою чергу, категорично забороняють застосовувати фізичні покарання дитини, отже, варто залучати представників церкви до тлумачення норм Біблії, приведення їх та норм права у відповідність та вироблення єдиної офіційної позиції церкви 3 приводу застосування фізичного покарання батьками дітей [2, с. 13-14].

Друга половина ХX сторіччя ознаменувалася підвищеною увагою до розвитку й дотримання прав людини, внаслідок цього науки соціального циклу стали глибше вивчати проблеми, пов'язані 3 порушенням прав людини, й пропонувати їх вирішення.

Аише в 70-ті роки ХХ століття проблема насильства в сім'ї стала суспільно значущою, а подружне насильство визнали неприпустимим на Заході. У Радянському Союзі насильства в сім'ї офіційно «не існувало». Як правило, вивчення цього феномену зводилось тільки до розгляду фізичного насилля відповідно до статей Кримінального кодексу. По-перше, «виносити сміття з хати» було негоже. Якщо тебе б’є чоловік - сама винна. А якщо і не винна - терпи, така жіноча доля. По-друге, навіть ті жінки, які все ж наважились подати заяву в правоохоронний орган, повертались додому ні з чим - заяву відмовлялися приймати [3, с. 74].

3 90-х рр. минулого століття відбулися кардинальні зміни щодо осягнення феномену насильства стосовно жінок, визнання його соці статевою проблемою і тим самим відкриття нового її бачення в розрізі гендерного права. 20 грудня 1993 р. Генеральна Асамблея ООН ухвалила “Декларацію про викорінення насильства щодо жінок», під впливом якої, відповідно до резолюції Комітету ООН з прав людини № 1994/45 від 4 березня 1994 р., призначено Спеціального доповідача ООН з питання про насильство над жінками, його причини і наслідки. Ці події змусили суспільство по-новому поди- витися на це явище, пов'язавши його $з$ проблемою гендерної дискримінації.

В Україні вперше на законодавчому рівні було врегульовано дане питання 15.11.2001 року, коли було прийнято у першій редакції Закон України «Про попередження насильства в сім'і». Даний Закон набрав чинності 20.03.2002 року. У даному нормативно-правовому акті вперше «визначено правові i організаційні основи попередження насильства в сім'ї, органи та установи, на які покладається здійснення заходів з попередження насильства в сім'ї».

Важливим етапом у реалізації принципів, закладених у Законі України «Про попередження насильства в сім'ї, стало прийняття у квітні 2003 року Кабінетом Міністрів України Постанови № 616 «Про затвердження порядку розгляду заяв та повідомлень про вчинення насильства в сім'ї або реальну його загрозу», яка визначає механізм прийняття, обліку й розгляду заяв i повідомлень про вчинення насильства в сім'ї місцевими органами у справах сім’і, молоді та спорту та органами внутрішніх справ [4]. Крім того, у вересні 2009 року була затверджена Інструкція щодо порядку взаємодії управлінь (відділів) у справах сім’і, молоді та спорту, служб у справах дітей, центрів соціальних служб для сім'ї, дітей і молоді та відповідних підрозділів ОВС з питань здійснення заходів 3 попередження насильства в сім'ї, якою визначений порядок здійснення системи заходів з попередження насильства в сім’ї органами й установами, які уповноважені здійснювати таке попередження, та механізм їх взаємодії [5].

Однак, таке українське законодавство щодо попередження насильства в сім’ї не відповідало сучасним міжнародним і європейським стандартам, адже до членів сім'ї не відносяться колишне подружжя та партнери; особи, старші за 18 років (які все ж таки все ще є дітьми для власних батьків у соціальному аспекті), та їх батьки, якщо проживають окремо, а також усі родичі, у разі їх окремого проживання. Крім того, тривалий час науковці 3 урахуванням міжнародного досвіду пропонували криміналізувати насильство в сім'ї. 
3 прийняттям 07.12.2017 року у нашій державі нового Закону України «Про запобігання та протидію домашньому насильству» та набранням чинності Законом України «Про внесення змін до Кримінального та Кримінального процесуального кодексів України з метою реалізації положень Конвенції Ради Свропи про запобігання насильству стосовно жінок і домашньому насильству та боротьбу з цими явищами» стало очевидно, що Україна визнає і привертає неабияку увагу до гостроти та глибини цієі проблеми. Цей Закон визначає організаційно-правові засади запобігання та протидії домашньому насильству, основні напрями реалізації державної політики у сфері запобігання та протидії домашньому насильству, спрямовані на захист прав та інтересів осіб, які постраждали від такого насильства [6].

Виокремлення насильства в сім'ї в самостійну соціальну проблему - тільки перший крок, спрямований на їі вирішення. На цьому шляху багато перепон. Це і брак чітких визначень, теоретичної бази, наукової основи; і нестача повної інформації про ступінь поширеності цього явища, його причини та умови; відсутність закону, що забезпечує захист жертв насильства в сім'ї; судова і правоохоронна практика, що не визнає проблему насильства в сім'ї; високий ступінь латентності явища: як об’єктивної, обумовленої тим, що про факти насильства в сім'ї не надходять заяви в правоохоронні органи, так і суб'єктивної, спричиненої приховуванням фактів насильства в сім'ї правоохоронними органами [7, с. 285-318].

\section{Результати дослідження}

Отже, вивчення будь-якої правового питання чи суспільного явища варто розпочинати 3 його історії. Адже дослідивши історичні особливості виникнення насильства, можливо сформулювати певні шляхи його подолання. Минуле століття характерне не лише страшними спалахами насилля. Воно назавжди посяде визначне місце в історії завдяки тому, що саме у цей час вперше отримали міжнародне визнання основні принципи дотримання прав людини.

Домашне насильство виразно попадає під порушення великої кількості міжна- родно визнаних прав людини, які держава зобов'язана відстоювати і захищати: права на життя і фізичну недоторканність, права не бути об'єктом знущань чи жорстокого, нелюдського або принизливого поводження, права на однаковий захист з боку закону і свободу від дискримінації за ознакою статі та інших. Як бачимо, витоки гендерної нерівності були детерміновані, перш за все, культурними та релігійними чинниками, а також особливостями правової системи у різних країнах. Як наслідок, домашне насиляя практично у всьому світі з давніх-давен і протягом тривалого часу визнавалось як належне, а в окремих джерелах соціальних норм було навіть зафіксовано у законодавчих формах.

Це негативне явище надзвичайно коштує всьому суспільству як $з$ матеріальної, так і з моральної точок зору. Наша держава продовжує перебувати в перехідному періоді, для якого характерна політична, законодавча, фінансово-економічна нестабільність. Україна визнає існування проблеми домашнього насильства, протидія якому є одним із пріоритетних напрямків державної політики.

\section{Література}

1. Курс «Побутового насильства»: посібник учасника. - Б. м., 1999. - 264 с.

2. Волощук А. М. Діяльність служби дільничних інспекторів міліції щодо попередження насильства в сім'ї: монографія /А. М. Волощук, Х. П Ярмакі, О. В. Ковальова. - Одеса: ОДУВС, 2013. - 218 с.

3. Каминская Н. А. Проблема насилия над женщинами / Н. $\Lambda$. Камин-ская // Реалізація державної політики стосовно дітей, молоді, сімей та затвер-дження гендерної рівності в суспільстві на території Донецької області: матеріали регіонального круглого столу (м. Донецьк, 18 лютого 2009 р.). - Донецьк: ДЮІ АДУВС ім. Е. О. Дідоренка, 2010. - 216 c.

4. Про затвердження порядку розгляду заяв та повідомлень про вчинення насильства в сім'ї або реальну його загрозу», яка визначає механізм прийняття, обліку й розгляду заяв і повідомлень про вчинен- 


\section{Кримінальне право, кримінальний процес та криміналістика}

У статті досліджено історичні аспекти виникнення та розвитку домашнъого насильства. Проаналізовано особливості домашнъого насильства на різних етапах розвитку нашоі держави.

Ключові слова: насильство, насильство в сім' $i$, домашне насильство, жертва насильства.

ня насильства в сім’ї місцевими органами у справах сім’і, молоді та спорту та органами внутрішніх справ.

5. Інструкція щодо порядку взаємодії управлінь (відділів) у справах сімऑі, молоді та спорту, служб у справах дітей, центрів соціальних служб для сім'ї, дітей та молоді та відповідних підрозділів органів внутрішніх справ 3 питань здійснення заходів 3 попередження насильства всім’ї, затверджена

\section{SUMMARY}

The article examines the historical aspects of the origin and development of domestic violence. The peculiarities of domestic violence at different stages of development of our state are analyzed.

Keywords: violence, domestic violence, domestic violence, victim of violence.

наказом Міністерства України у справах сім’і, молоді та спорту, Міністерствавнутрішніх справ України від 7 вересня 2009 рокуN 3131/386

6. Закон України «Про запобігання та протидію домашньому насильству»від7 грудня 2017 року № 2229-19 [Електронний ресурс]. - Режим доступу:http://zakon3. rada.gov.ua/laws/show/2229-19.

7. Берковец $\mathcal{\lambda}$. Агрессия: причины, последствия, контроль / $\Lambda$. Берко-вец. - СПб.: Прайм-ЕВРОЗНАК, 2001. - 512 с. 